\title{
Pohnpeian Language
}

National Cancer Institute

\section{Source}

National Cancer Institute. Pohnpeian Language. NCI Thesaurus. Code C154080.

An Austronesian Micronesian language spoken as the indigenous language of the island of Pohnpei in the Caroline Islands. 